Article

\title{
Emerging Livelihood Vulnerabilities in an Urbanizing and Climate Uncertain Environment for the Case of a Secondary City in Thailand
}

\author{
Astrud Lea Beringer * and Jutamas Kaewsuk \\ International Research Center for Sustainable Environmental Management in Greater Mekong Sub-Region, \\ Faculty of Environment and Resource Studies, Mahasarakham University, Kantharawichai 44150, Thailand; \\ jutamas.k@msu.ac.th \\ * Correspondence: beringer.a@msu.ac.th; Tel.: +66-958-2015-11
}

Received: 29 March 2018; Accepted: 2 May 2018; Published: 7 May 2018

\begin{abstract}
Increasing flood risks in Thailand are leading to new challenges for flood management and subsequently for livelihoods, which are still significantly agricultural. Policy makers prefer building flood protection infrastructure over utilizing non-structural measures like urban planning regulations to mitigate risks. We argue that unplanned urbanization intensifies flood risks and livelihood vulnerability and may even create new poverty patterns in peri-urban areas. However, urbanization can also strengthen the adaptive capacity of people in flood risk areas by providing more secure employment opportunities. We assess the livelihood vulnerability of Pra Lab, a peri-urban area of Khon Kaen City in Northeast Thailand, using a qualitative and quantitative analysis. The study relies on a vulnerability index developed from a household survey and rainfall statistics, complemented by household in-depth interviews. We further identified factors of unplanned urbanization in Khon Kaen City and Pra Lab through interviews with relevant local government offices. Our findings show that Pra Lab's household livelihoods are moderately vulnerable to flood due to high financial (i.e., income, debts) and physical vulnerability (i.e., housing, urban systems, infrastructure). Major factors of unplanned urbanization that contribute to flood risks are lack of land use regulations, inefficient monitoring of land and house elevations, reduced pervious surfaces, ineffective water governance and insufficient wastewater treatment.
\end{abstract}

Keywords: urbanization; flooding; livelihood vulnerability; peri-urban; governance; Thailand

\section{Introduction}

Khon Kaen City (KKC), a secondary city in Northeast Thailand, has rapidly urbanized over the past 20 years without an effective and ecologically sound development plan. As the city's margins have expanded into nearby rural areas, people's livelihoods have shifted [1]. Since the 1960s, Thailand's National Economic and Social Development Plans (NESDP) fostered economic growth and regional integration in secondary cities, driving KKC's urban growth [2]. Today, the Thai government envisions $\mathrm{KKC}$ as an important logistical and economic hub of the region [3]. However, urban growth in KKC occurred widely unregulated; the lack of land use regulations for over ten years led to vast land conversions [4], which caused a change in the city's physical infrastructure and reduced essential ecological buffers. Pervious surfaces have gradually diminished and new infrastructure has blocked the natural floodway.

KKC endures more frequent and severe floods; precipitation over the past decade has increased in intensity, that is, more days with intense rainfall (about $8 \%$ above the 30-year average of $1299.9 \mathrm{~mm}$ ) and decreased in number of days (15\% below the annual average of 95 days) [5]. Urban planning 
without considering projected increased precipitation from climate change can have negative and long-lasting implications for the livelihood of the most vulnerable citizens. These are not only the poor and marginalized in the city [6] but also people who rely mainly on agriculture in urban fringe areas [7].

\subsection{Flood Risk Area}

Pra Lab, a peri-urban adjacent municipality to KKC, is located downstream of the city's catchment area, thus most affected by floods. Growing flood risks pose increasing challenges to Pra Lab communities' livelihoods because most are engaged in rice and fish farming, which requires controlled maintenance of flood levels. KKC, the capital of Khon Kaen Province and Mueang Khon Kaen District, is surrounded by four adjacent municipalities one of which is Pra Lab (see Figure 1). For the purpose of this study we refer to KKC's entire peri-urban area as defined in the city land use plan. KKC has a total area of 46 square kilometers and a population (2017) of 120,143, among the most populous cities in Thailand [8]; Pra Lab has a population of 22,347 people [8].

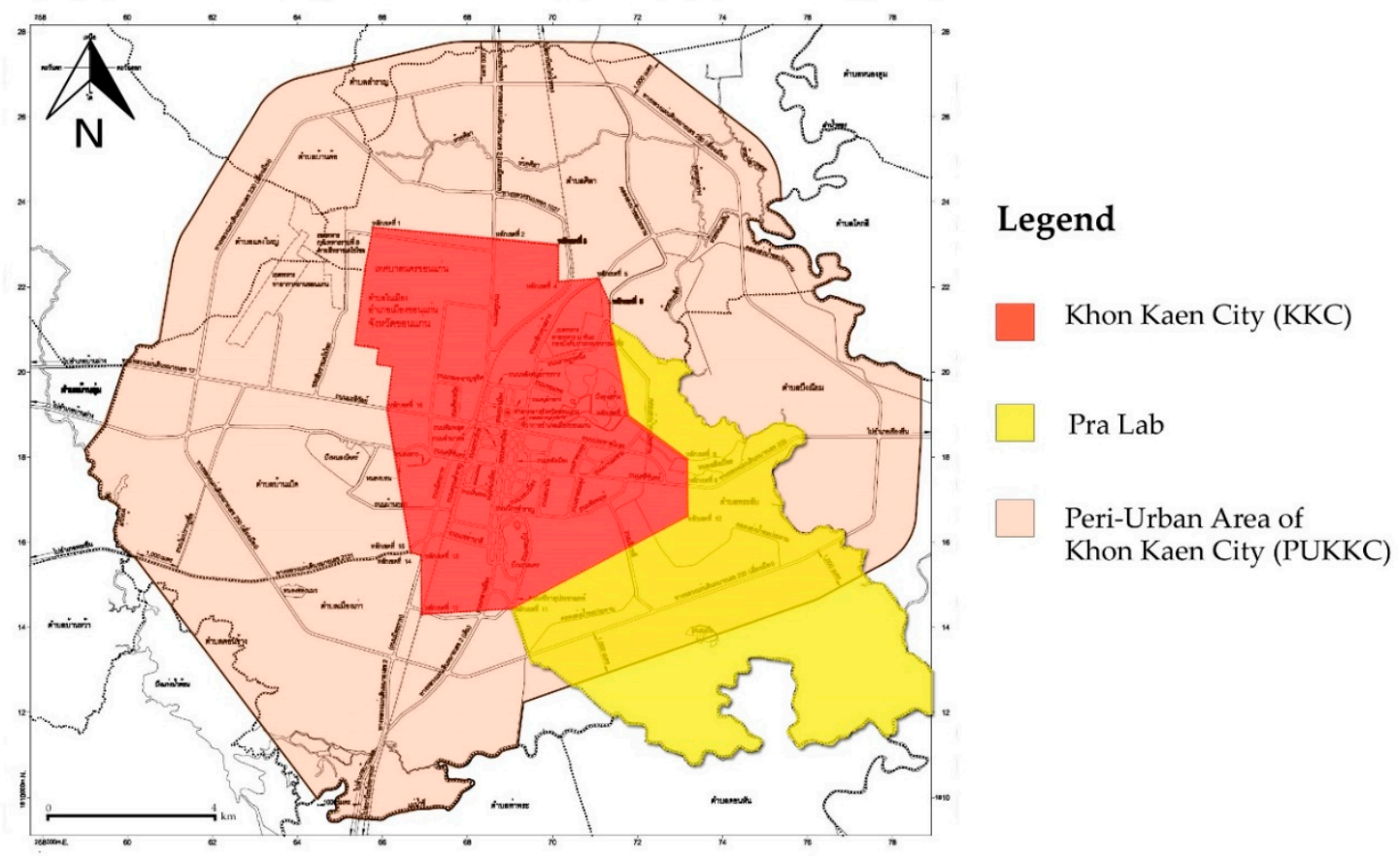

Figure 1. Map of Khon Kaen City (KKC) and its peri-urban area, including Pra Lab; reproduced from [9].

Since the 1990s, Thailand experienced quick economic growth and rapid urbanization with a drastic reduction in poverty [10]. The urban population grew from 32 percent in 2000 to 53 percent in 2017 [10]. During the same time span, poverty dropped from 42 percent in 2000 to 10 percent in 2014 [10]. Despite the positive economic benefits of urbanization, there are limitations. Poverty and inequality are expected to become more volatile due to decreasing agricultural prices and ongoing climate risks [11].

KKC experienced similar growth and socio-economic changes. In the past decades, the city transformed into a major logistic and economic hub for regional integration due to three central developments [2]: the Thai government's NESDPs that attracted numerous Chinese-Thai investors and increased rural to urban migration; KKC's distinctive location as the geographic center of Northeast region; the establishment of the first university in the region in 1964. The global trend of declining labor force in the agricultural sector is also reflected in Thailand [12,13]. In urban centers, younger people (below 25) enter the nonfarm labor market in greater numbers [14,15]. 
Climate variation creates further challenges for PUKKC's urban growth and people's livelihoods. In the past 30 years, incidents of higher rainfall have increased in Thailand [16] as they have in other parts of Southeast Asia [7], intensifying floods. In 2011, the country was hit by a 100-year flood that caused the death of over 800 people and vast economic damages of at least US\$45 billion [17].

Flood-prone Pra Lab is bordered by two major rivers, Chi and Phong, which are connected through Pra Keu Stream, historically suitable for rice farming (see Figure 2). However, changes in precipitation patterns $[5,16]$ have turned agriculture into an uncertain and risky livelihood. In October and November 2017, severe floods destroyed the total crop of 8022 rai or about 1283 hectares of farmland in Pra Lab and affected the livelihoods of 351 households [18]. In the past, typical annual monsoons resulted in minor flooding but in 2004, 2008 and 2011, PUKKC experienced more substantial floods [19], which occur when there is a combination of river overflow and rainwater runoff from the higher situated municipalities. In 2011, floodwater remained for up to 90 days in Pra Lab [1], critically constraining people's access to key infrastructure and public services such as roads, health centers, food markets and schools [1]. Moreover, high rates of diarrhea, pneumonia, dermatitis and dengue fever, recorded at the local hospital in Pra Lab in 2011, indicated a direct link of contaminated floodwater to the communities' health [1].

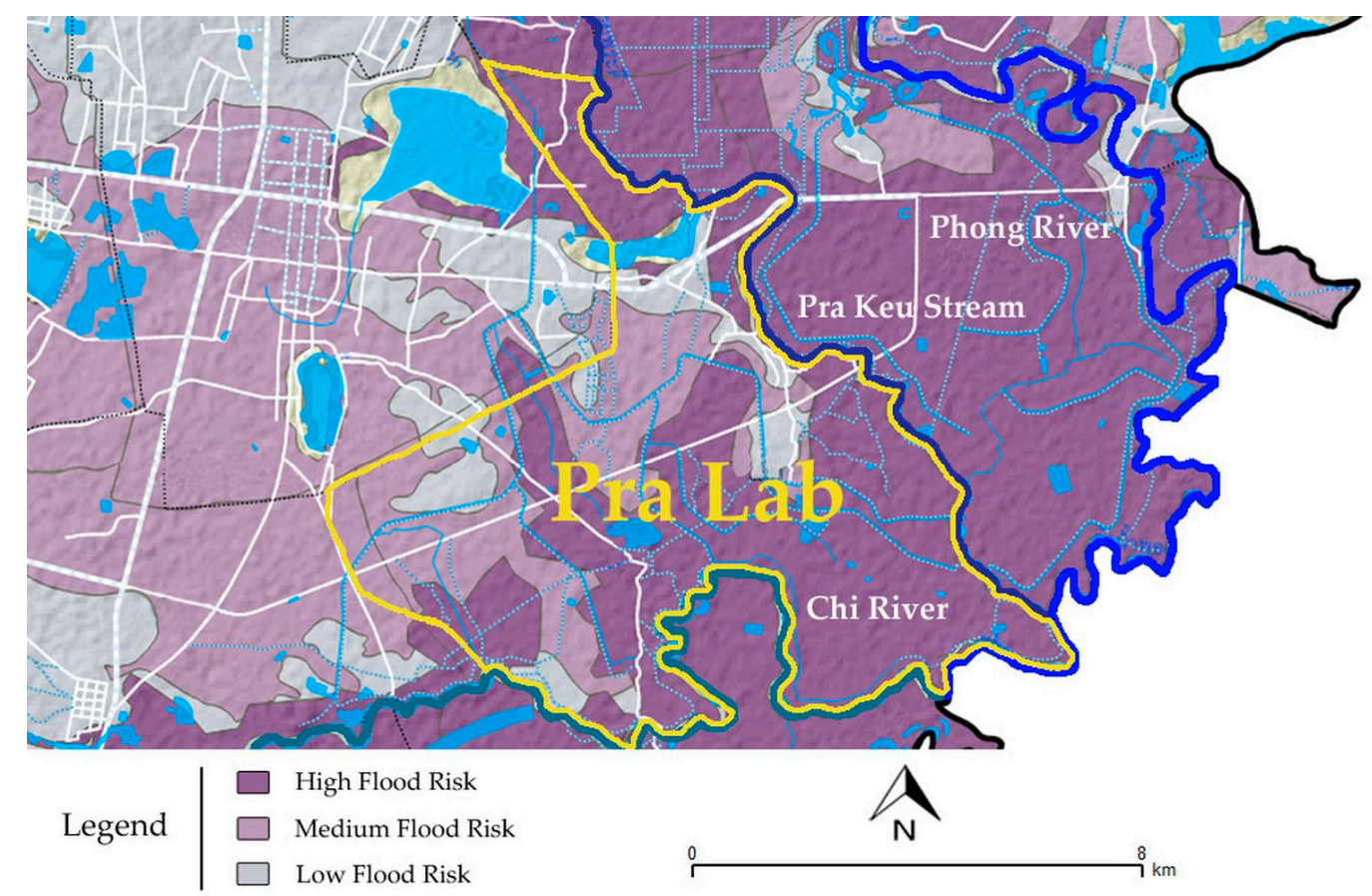

Figure 2. Hydrological landscape and flood risk areas in Pra Lab; reproduced from [20].

\subsection{Urbanization, Climate Change, Vulnerability and Poverty}

Political ecologists identify increased floods not only as a result of climate change and heavy rainfall but also as outcomes of political processes [21]. Unplanned urban growth with mismanaged infrastructure development and land use changes reflects those outcomes [22,23]. In the context of this study, we interpret unplanned urbanization as a result of weak urban governance as well as the absence, or insufficient implementation, of important planning regulations for example, land use plans. Urbanization can be described as a transformative process rather than a fixed state and its negative impacts are closely intertwined with global environmental change [24]. In an urbanizing Asia, Friend and Thinphanga [25] identified a negative correlation between investment in the conversion of floodplains and the conservation of natural waterways as flood protection. Roachanakanan [26] argued that wetlands, which have an essential function as floodways, have widely disappeared in 
Thailand because policy makers prefer structural to non-structural measures, for example, building more floodwalls rather than strengthening urban planning regulations. A complex systems and actor-oriented approach that goes beyond site-specific measures may be required to respond to emerging vulnerabilities caused by urbanization and climate change [25].

Marshall et al. [27] have and Ravetz et al. [28] have identified peri-urban areas as particularly vulnerable to the implications of urbanization such as poverty and social displacement. Features of peri-urban areas are low population density, small landholdings, a lack of spatial governance, scattered settlements, mainly agricultural but also diverse livelihoods, uncoordinated conversions of agricultural to residential land development, environmental degradation and a lack of service provision $[27,28]$. Thailand's peri-urban areas are in particular prone to land conversions of agricultural to residential and industrial land [29].

Together with increasing climate hazards, unregulated urbanization exacerbates livelihood vulnerabilities in peri-urban areas in Asia [30,31]. A case study in Da Nang, Vietnam, describes how infrastructure expansion and rainfall pattern changes increase flood risks and impact the livelihoods of peri-urban communities, who are predominantly agricultural [30]; particularly the peri-urban communities' low skills for nonfarm jobs constrain their capacity to adapt to floods [30]. A case study in Surat, India, also identifies a high physical and financial vulnerability to flood for peri-urban households, who rely on farming or daily wage labor as major source of income [31].

The Asian Development Bank [32], Ferre et al. [33], Ravallion et al. [34] and the World Bank [35] have diverse perceptions on the impact of urbanization on poverty reduction. While the Asian Development Bank emphasizes that urbanization can be a positive factor in growth and poverty reduction [32] by providing new employment opportunities, others stress [33-35] that urbanization can also contribute to new urban poverty patterns such as inadequate access to basic services. Despite the positive aspects of urbanization, the aftermath of substantial floods like the 100-year flood in Thailand in 2011 showed that the livelihood only worsened of those, who were most affected and already poor [36].

In this paper, we aim to understand the relationship between urbanization, climate risk, vulnerability and poverty in KKC, presented in a case study in Pra Lab. Our study has two major objectives: (i) assess the livelihood vulnerability of Pra Lab's communities using a Livelihood Vulnerability Index (LVI); (ii) analyze key problems of unplanned urbanization in KKC that contribute to flood risks and influence the livelihood vulnerability of Pra Lab communities. We argue that the outcomes of unplanned urbanization contribute to the magnitude of floods and consequently to the impact on livelihoods, particularly in flood risk and peri-urban areas. If these livelihood vulnerabilities continue to increase, new urban poverty patterns may emerge.

\section{Materials and Methods}

\subsection{Conceptual Frameworks}

In this research, we have used the Climate Resilience Framework (CRF) and the Sustainable Livelihood Approach (SLA) as conceptual frameworks. The CRF assesses vulnerabilities and risks, identifies resilience strategies and initiates an inclusive learning process to formulate measures and actions that can tackle the uncertainties of climate change in an urban environment [37]. The framework defines urbanization as a transformative process [37]. The CRF draws more on resilience than adaptation and points to the interaction of urban systems, agents and institutions [38]. Urban systems (both ecosystems and infrastructure systems) are affected by climate impacts and effect social agents (both individuals and organizations), who can plan and address climate effects directly [38]. Institutional structures can restrict and support the actions of agents [38].

The SLA assesses five types of assets or capitals, that is, human, social, natural, physical and financial [39], as well as their vulnerability context such as shocks, trends or seasonality [40]. The SLA defines vulnerability as 'lack of resilience to changes that threaten welfare ... [which] can take form 
of sudden shocks, long-term trends, or seasonal cycles ... [that] usually bring increasing risk and uncertainty' [41] (p. 5). The degree of vulnerability is based on external threats to the welfare of households, individuals and communities [42]. Poverty is hereby recognized as more than income or consumption poverty but as multidimensional aspects of changing socio-economic wellbeing [41].

\subsection{Methods}

Our research employs a quantitative and qualitative approach: (i) a review of relevant literature and public documents; (ii) a household survey; and (iii) in-depth interviews with households and policy-makers. Between February and April 2017, we prepared the study by reviewing secondary data including plans, maps and documents of urbanization patterns, historical climate data and water and land management in PUKKC. Concurrently, we held preliminary meetings in PUKKC with five municipalities in PUKKC, including KKCM and Pra Lab, as well as the Water Resource Management Research Center at the Faculty of Engineering, Rajamangala University of Technology Isan and the Department of Civil Engineering at the Faculty of Engineering, Khon Kaen University. Through these meetings we collected further review material and received suggestions for suitable interview partners.

\subsubsection{Household Survey}

We prepared a household survey to create a LVI. The index is embedded in the SLA, which assesses different impacts of flood on livelihoods in the context of urbanization by integrating multiple issues, such as flood frequency and dependency on agriculture as major source of income, into one index [43]. Contrary to vulnerability assessments for climate projections, the LVI measures the strength of the current livelihoods of communities and their strategies to address climate related impacts [43]. In addition, we developed the LVI-IPCC using the Intergovernmental Panel on Climate Change's (IPCC, Geneva, Switzerland) three contributing factors to vulnerability-exposure, sensitivity and adaptive capacity. The calculation of the two indices are based on a study developed and tested first by Hahn et al. [43] in Mozambique. Our study relies predominantly on primary data, collected through a survey with 236 households and a review of rainfall statistics; the data of nine in-depth interviews with selected households complemented the analysis of the LVI.

We developed a list of 45 indicators or sub-components a priori for the five assets of the LVI and its 11 major-components (see Appendix A, Table A1), defined through secondary data sources and the purpose of this study. The five assets are human, social, natural, physical and financial. The 11 major-components are health, livelihood strategy, education, land, natural resources, natural disasters and climate variability, socio-demographic profile, social networks, housing and means of production, urban systems and finance and income. We used this list of indicators to create a household survey with 57 closed questions; these questions were first developed in English and then translated into Thai.

We tested the survey in the field, revised the questionnaire and conducted the survey with 236 households over eight days in June 2017. We selected households based on three criteria: (i) most often flooded villages, that is, 14 out of 19, at the suggestion of the Sub-District Head of Pra Lab; (ii) most often flooded streets, identified by the heads of the villages; and (iii) availability at the time the survey was conducted. The second author, a native Thai speaker and five Thai students from Mahasarakham University (MSU, Kantharawichai, Thailand), who spoke the local dialect, surveyed the households one-on-one. The survey days started between 6 to 7 am and lasted no longer than four hours; one questionnaire took between 15 to $40 \mathrm{~min}$. Since many household heads had only primary education, questionnaires were verbally administered. Table 1 shows the demographics of Pra Lab survey respondents.

The data entry of the collected survey questionnaires was carried out by the second author and the five students from MSU using Microsoft Excel. Each question that was answered with "yes" was coded with 1; each question that was answered with "no" was coded with 0 . The data was calculated by percentage or average depending on the related indicator. 
Table 1. Demographics of Pra Lab survey respondents.

\begin{tabular}{cccccc}
\hline \multicolumn{2}{c}{ Gender of Respondent } & \multicolumn{2}{c}{ Age of Respondent } & \multicolumn{2}{c}{ Household Ratio } \\
\hline Male & Female & $\mathbf{1 8 - 4 9}$ & $50<$ & $<\mathbf{1 5} \&>\mathbf{6 5}$ & $\mathbf{1 5 - 6 4}$ \\
\hline $73.3 \%(n=173)$ & $26.7 \%(n=63)$ & $24.5 \%(n=58)$ & $75.4 \%(n=178)$ & $24 \%$ & $76 \%$ \\
\hline
\end{tabular}

The vulnerability indices were calculated by both authors evaluating the data using Microsoft Excel. We adopted the LVI and LVI-IPCC equations from the formulas developed by Hahn et al. [43]. The LVI applies a balanced weighted average [44] approach where each sub-component contributes equally to the overall index, although each major component has different numbers of sub-components [43]. To standardize the sub-components, Hahn et al. [43] used the equation of the human development index of the United Nations Development Programme [45], which is used to calculate life expectancy [43]:

$$
\text { index }_{S_{P}}=\frac{S_{P}-S_{\min }}{S_{\max }-S_{\min }}
$$

where $s_{P}$ is sub-component for Pra Lab $P$ and $s_{\min }$ and $s_{\max }$ are the minimum and maximum values for each sub-component. Subsequently, to standardize the sub-component values, we calculated the value of each major component using the following equation [43]:

$$
M_{P}=\frac{\sum_{i=1}^{n} i_{n d e x_{s_{P} i}}}{n}
$$

where $M_{P}=$ one of the 11 major components for Pra Lab $P$; index SPi $_{\text {in }}$ represented the value of the sub-component $s$ indexed by $i$ of major component $M_{P} ; n$ is the number of sub-components in each major component. The major components are scaled from 0 (least vulnerable) to 1 (most vulnerable).

After the calculation of the values for each of the 11 major components for Pra Lab, they were averaged or aggregated to values for the five livelihood assets (Human Capital (H), Natural Capital (N), Social Capital (S), Physical Capital (P) and Financial Capital (F)) using Equation (3), before applied in equation (4) to obtain the weighted average LVI for Pra Lab. The five assets are scaled from 0 (least vulnerable) to 1 (most vulnerable) [43]:

$$
\begin{gathered}
L V I_{P}=\frac{\sum_{i=1}^{11} w_{M i} M_{P i}}{\sum_{i=1}^{11} w_{M i}} \\
L V I_{P}=\frac{w_{H} H_{P}+w_{N} N_{P}+w_{S} S_{P}+w_{P} P_{P}+w_{F} F_{P}}{w_{H}+w_{N}+w_{S}+w_{P}+w_{F}}
\end{gathered}
$$

where $L V I_{P}$ is the Livelihood Vulnerability Index of Pra Lab $P$; $w_{M i}$ is the weight of each major component $\left(w_{H} w_{N} w_{S} w_{P} w_{F}\right)$, which are the weight values of each of the five livelihood assets or capitals. We aggregated the major components to values for the five livelihood assets before obtaining the weighted average LVI. The LVI was scaled from 0 (least vulnerable) to 1 (most vulnerable).

The LVI-IPCC was calculated with the same Equations (1)-(3) that were applied for the calculation of the sub-components and five livelihood assets. The following equation was used to calculate the three contributing factors of the LVI-IPCC [43]:

$$
C F_{P}=\frac{\sum_{i=1}^{n} w_{M i} M_{P i}}{\sum_{i=1}^{n} w_{M i}}
$$

where $C F_{P}$ is an IPCC defined contributing factor, that is, exposure, adaptive capacity and sensitivity, for Pra Lab P; $M_{P i}$ are the major components for Pra Lab indexed by $i$; $w_{M i}$ is the weight of each major component; and $n$ is the number of major components in each contributing factor. Contributing factors 
are on a scale from 0 (least vulnerable) to 1 (most vulnerable). Once the three contributing factors to vulnerability were calculated, they were combined using the following equation [43]:

$$
L V I-I P C C_{P}=\left(e_{P}-a_{P}\right) * s_{P}
$$

where $L V I-I P C C_{P}$ is the LVI for Pra Lab $P$ expressed using the IPCC vulnerability framework; $e$ is the value for exposure of Pra Lab $P$ (equivalent to the major component "natural disaster and climate variability"), $a$ is the value for adaptive capacity of Pra Lab $P$ (weighted average of the major components: livelihood strategies, education, socio-demographic profile, social networks, finances and income and housing and means of production) and $s$ is the value for sensitivity of Pra Lab $P$ (weighted average of the major components: health, land, natural resources and urban systems). The scale of the LVI-IPCC ranged from -1 (least vulnerable) to 1 (most vulnerable).

\subsubsection{In-Depth Interviews}

After completing the survey data collection and evaluation, we conducted in-depth interviews with nine household heads in Pra Lab as well as with 14 government officers between June and July 2017. We selected household interviewees (see Table 2) based on significant answers provided in the survey, such as indication of low annual household income or high number of experienced floods.

Table 2. Demographics of Pra Lab interview respondents $(n=9)$.

\begin{tabular}{cccc}
\hline \multicolumn{2}{c}{ Gender } & \multicolumn{2}{c}{ Age } \\
\hline Male & Female & $\mathbf{1 8 - 4 9}$ & $\mathbf{5 0 <}$ \\
\hline $22 \%(n=2)$ & $78 \%(n=7)$ & $22 \%(n=2)$ & $78 \%(n=7)$ \\
\hline
\end{tabular}

We selected government interviewees based on suggestions during meetings with different municipalities and university departments in KKC prior to the data collection. Government interviewees were affiliated with following offices:

- Khon Kaen City Municipality (KKCM)—three different sections

- Pra Lab Municipality (PLM) - three different sections

- Regional Environmental Office 10 (REO10)

- Provincial Department of Public Works and Town \& Country Planning (PDPT) Khon Kaen

- Chi River Basin Organization (CRBO)

- $\quad$ Royal Irrigation Department (RID) Khon Kaen

- Provincial Department of Disaster Prevention and Mitigation (PDDPM) Khon Kaen

- Ubolratana Dam

- Northeastern Meteorological Center Khon Kaen

- Provincial Public Health Department Khon Kaen

We audio recorded all interviews and took notes during the interviews. The second author interviewed the subjects in Thai, intermittently translating to the first author, so that she could generate additional questions during the interviews. Since we did not speak the local dialect, a student from MSU helped to conduct the household interviews; interviews with government officials were carried out in Thai. Interviews lasted up to $60 \mathrm{~min}$. The second author summarized the interviews, which were filtered by relevance, using the audio recordings and personal notes. We applied a qualitative content analysis, which is a technique for systematic text analysis through the formulation of categories [46], to evaluate the interview data.

The household interviews complemented the quantitative analysis of the vulnerability indices. We developed a range of 68 open-ended questions concerning flood and its impacts, divided into five stages (i.e., before flood, during flood, flood loss and response, recovery, aftermath). A sample 
question in the first stage: 'Have you experienced any severe floods before in Pra Lab? If so, how many times?' (see Appendix B) We loosely followed the questionnaire, adjusting questions to the flow of the interview or even skipping questions that were not relevant to the respondent. The first author analyzed the interview data by sorting the information to categories, based on the 11 major components of the LVI.

The government interviews supported the identification of key problems of unplanned urbanization in PUKKC. We developed a range of 17 topical open-ended questions regarding urban planning and governance of water and land use, as well as flood protection in PUKKC. A sample question: 'How do you think poor land use contributes to flooding in Pra Lab?' During the interviews, we became more specific if we expected the office was more knowledgeable on a specific subject area. The first author sorted the interview information by forming two major categories (i.e., reasons for flood, challenges of flood). These two major categories had several sub-categories such as land use changes or water management. Next, she analyzed the two major categories by sorting again major infrastructure problems of unplanned urbanization in PUKKC.

\section{Results}

\subsection{Survey Results}

The overall livelihood vulnerability (LVI) for Pra Lab communities had a value of 0.375 (see Table 3 and Appendix A, Table A2) ( 0 = least vulnerable; 1 = most vulnerable), which means that Pra Lab is moderately vulnerable to the impact of flood. The physical (0.503) and financial vulnerability $(0.485)$ were highest, followed by the natural ( 0.359$)$ and human vulnerability $(0.357)$; the social vulnerability (0.257) was lowest (see Table 3, Figures 3 and 4).

Our findings showed that Pra Lab's physical vulnerability index was highest. Although most buildings are durable (concrete) (0.013), long durations of flooding (more than seven days) in the area (0.768) and in houses (0.814), create dangerous physical conditions. Inadequate access to roads and streets in the event of severe flooding for more than half of the surveyed households (0.589) also contributed to the high index. Moreover, the community lacks an adequate wastewater treatment system (0.920).

Table 3. Pra Lab livelihood vulnerability for five assets and 11 major components. $(0=$ least vulnerable; $1=$ most vulnerable).

\begin{tabular}{ccc}
\hline Asset & Major Component & Observed Vulnerability \\
\hline Human & Health & 0.357 \\
& Livelihood strategies & 0.223 \\
& Education & 0.407 \\
& & 0.442 \\
\hline Natural & Land & 0.359 \\
& Natural resources & 0.357 \\
& Natural disaster and climate variability & 0.501 \\
& Socio-demographic profile & 0.217 \\
\hline Physical & Social networks & 0.257 \\
& Housing and means of production & 0.193 \\
& Urban Systems & 0.322 \\
\hline Financial & Finance and income & 0.503 \\
\hline Overall LVI (weighted average of H, N, S, P, F) & 0.398 \\
\hline & Hote & 0.607 \\
\hline
\end{tabular}

Note: Index values were interpreted as relative values to be compared within this research sample only. 


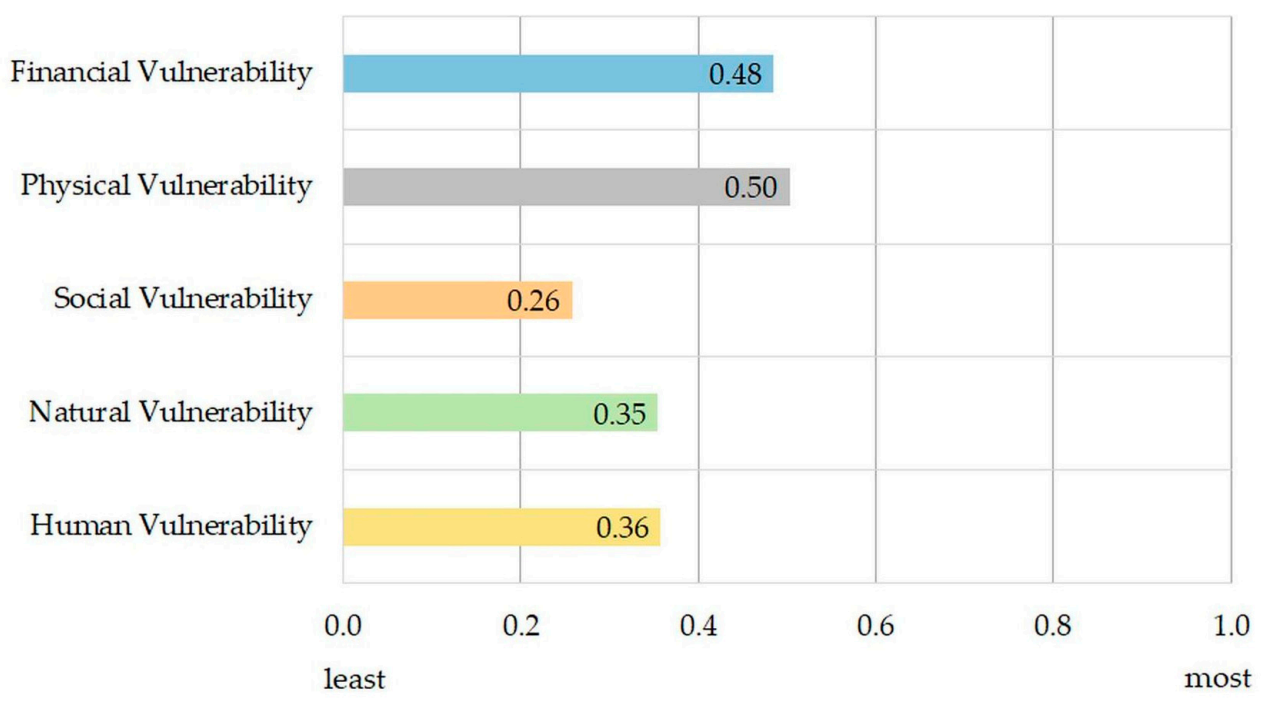

Figure 3. Pra Lab livelihood vulnerability to flood for five assets.

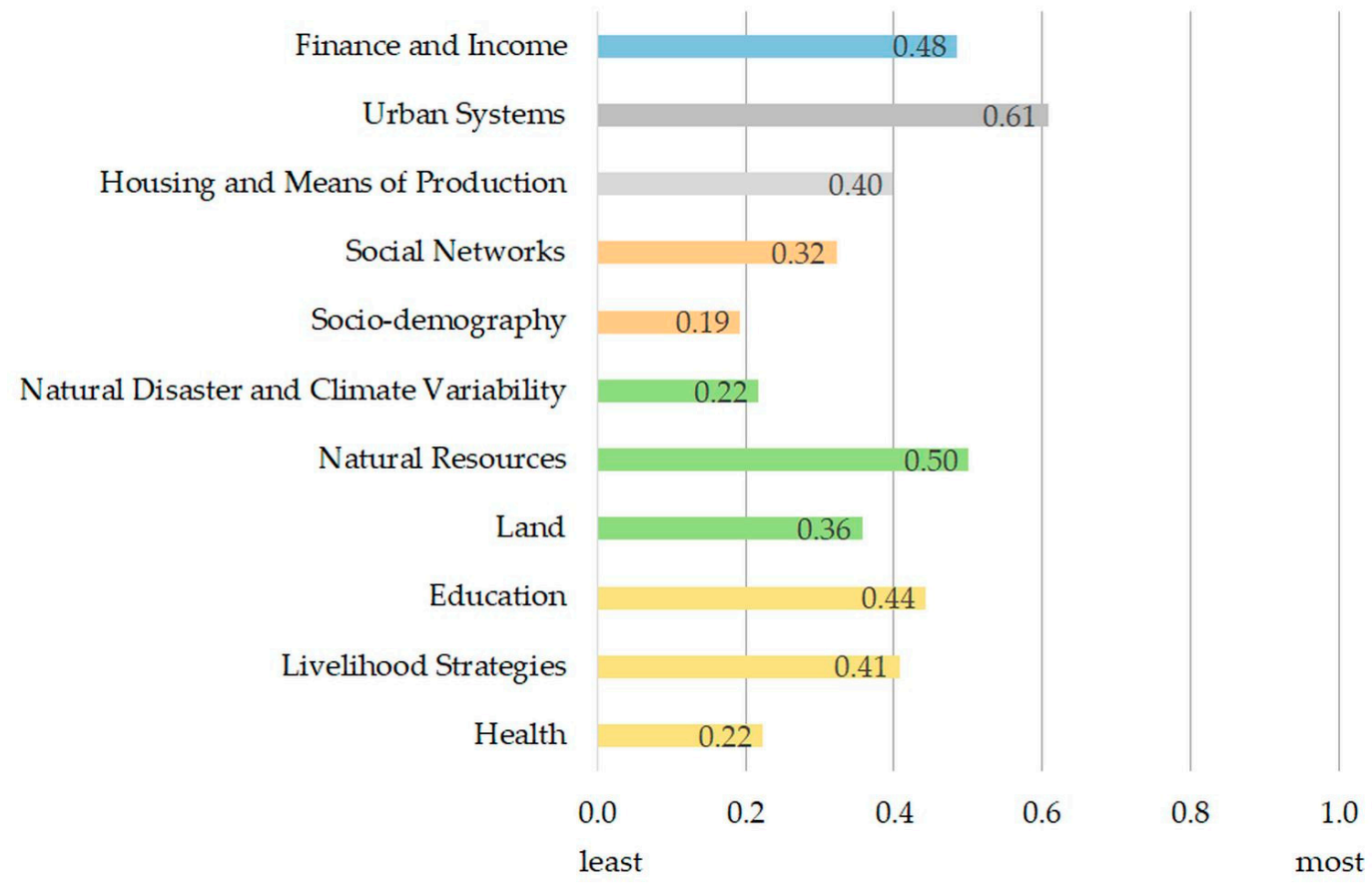

Figure 4. Pra Lab livelihood vulnerability to flood for 11 major components.

The financial vulnerability index was second highest. Although the surveyed households are-as of the national poverty line-not considered poor, more than half of the surveyed households $(0.591)$ have a net income that is lower than 100,000 Thai Baht or about USD $\$ 3187$ per year ( 1 USD $=31.3788$ Thai Baht as of 6 March 2018 [47]), enough for a hand-to-mouth existence but inadequate for accruing economic buffers. Many people had no insurance or received insufficient government compensation to recover losses (0.523), thus accumulated large financial debts (0.523) from flood damages and reported a significant income reduction due to agricultural production losses (0.773).

Pra Lab's human asset vulnerability was moderate to high compared to the other four assets. The high flood impact on rice and fish farming (0.704) and dependency of half of the surveyed households on an agricultural livelihood as their major source of income (0.506) contributed most to Pra Lab's human vulnerability. More than half of the respondents also indicated that they use 
more than $50 \%$ of their harvest for their own consumption (0.640). At least one household member is working outside of Pra Lab for almost half of the surveyed households (0.458). This was significant for some farmers to prevent higher livelihood losses during floods. A transition from rural to urban livelihood appears, however, more challenging for the majority, as more than two thirds of the surveyed households' heads have only primary school education (0.873).

The health component index (see Figure 4 ) was relatively low (0.223), although data we obtained from the Regional Environmental Office 10 shows that Pra Keu stream had a very poor to extremely poor water quality index in 2013 [48]. Despite that, there is a lack of evidence of possible community health consequences due to the polluted water of Pra Keu stream, when inundated in the event of heavy rainfall.

The natural vulnerability was moderately high since the majority $(0.700)$ of the surveyed households have small land ownership (less than 10 rai or 1.6 hectares) and can only cultivate the 1st and/or 2nd of the maximum of three crops per year (0.958).

The social vulnerability was lowest. The low-moderate vulnerability of the dependency ratio index (0.329) reflects that the proportion of people between the age of 15 and 65 was twice as high as the proportion of those below 15 and above 65 years among the surveyed households. The neighborhood solidarity during flooding was relatively good among the surveyed households in Pra Lab (0.114), although one third (0.338) of them indicated not engaging in neighborhood-support-networks for floods.

The LVI-IPCC was low with a value of -0.069 (see Table 4); the scale of the LVI-IPCC ranges from -1 (least vulnerable) to 1 (most vulnerable). The contributing factor of exposure to the impact of flood was low for Pra Lab (0.217) (see Figure 5) because the index relies partly on an indicator that states the number of severe floods as experienced by the surveyed households and announced officially as disaster; minor floods that come with the annual monsoon or not announced as a disaster were excluded in the exposure index and thus, may be unsuitable. We considered the usage of official flood frequency records in Pra Lab not suitable, because these statistics also include only floods officially announced as a disaster. The sensitivity factor to the impact of flood was significantly high (0.407), mostly due to the high vulnerability index of the land and urban systems components. At the same time Pra Lab's communities' adaptive capacity was moderately high (0.387) (see Figure 5). Pra Lab's low social vulnerability index is reflected in the high contributing factor of adaptive capacity and indicates that the communities are able to support each other despite the absent of efficient and effective governmental support. The high adaptive capacity also shows flexibility to implement adaptive strategies, which could consequently strengthen financial stability.

Table 4. Pra Lab vulnerability for the three Livelihood Vulnerability Index- Intergovernmental Panel on Climate Change (LVI-IPCC) contributing factors.

\begin{tabular}{|c|c|c|}
\hline Contributing Factors & Major Components & Observed Vulnerability \\
\hline Adaptive Capacity & $\begin{array}{l}\text { Livelihood Strategies } \\
\text { Education } \\
\text { Socio-Demography } \\
\text { Social Networks } \\
\text { Finance and Income } \\
\text { Housing and Means of Production }\end{array}$ & 0.387 \\
\hline Sensitivity & $\begin{array}{l}\text { Health } \\
\text { Land } \\
\text { Natural Resources } \\
\text { Urban Systems }\end{array}$ & 0.407 \\
\hline Exposure & Natural Disaster and Climate Variability & 0.217 \\
\hline \multicolumn{2}{|c|}{ LVI-IPCC $=($ Exposure - Adaptive Capacity $) \times$ Sensitivity } & -0.069 \\
\hline
\end{tabular}

Note: Index values were interpreted as relative values to be compared within the research sample only. 


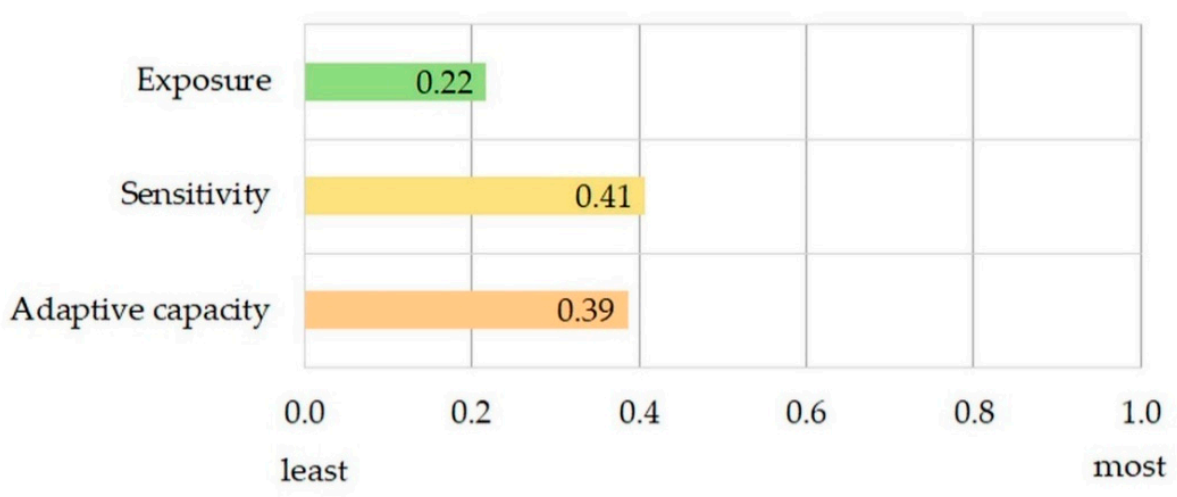

Figure 5. Pra Lab vulnerability for the three LVI-IPCC contributing factors.

\subsection{Interview Results}

In a qualitative content analysis, we first elaborated the quantitative analysis of our vulnerability indices with data from household interviews and then identified key infrastructure problems of unplanned urbanization in PUKKC.

\subsubsection{Interviews with Households}

For people who relied primarily on farming, physical vulnerability was inextricably linked to financial vulnerability. Interview respondents, most of which were farmers (57\%), pointed out that floodwater reached up to two meters deep on farms and an average of 30 centimeters in houses during the most severe flood in 2011 and remained for four and three months, respectively. Most interviewees felt constant stress and some also believed that the foul-smelling polluted water caused them skin infections. A few people also had to move temporarily to other houses. Floods often come shortly before the harvest time between October and November, destroying the total crop.

Before flooding increased, debts from agricultural investments were often already an issue, as one interview respondent stressed. Government compensations for flood damages, which are capped at 300,000 Thai Baht or US\$ 9558, were insufficient for several interview respondents to recover from the flood losses. The money was often used to cover immediate needs such as food expenses during floods but could not compensate for lost investments. Some interviewees indicated that they had to borrow money from the Ministry of Agriculture and Cooperatives, a bank, or even a loan shark with high interest rates.

Growing climate risks, financial insecurity and expenses for higher education for the farmers' children may reduce the number of yearly crops even more and force them to sell or rent out their land permanently, as one interview respondent emphasized. Several interviewees believe that households, who rely mainly on farming, are most affected by floods. They also foresee a growing transition from rural to urban livelihood practices in Pra Lab, since climate risks are growing and young Thais prefer nonfarm jobs with a regular income to physically demanding farm work with income instability.

\subsubsection{Interviews with Policy Makers}

Based on the results from interviews with government officials, we found that unplanned urbanization in PUKKC contributes to the magnitude and extent of flooding in Pra Lab and influences the livelihood vulnerability. We identified these following key infrastructure problems:

Land use plan: An official from KKCM emphasized that an absence of land use regulations allowed rapid land use changes and resulted in a significant reduction of green areas in PUKKC. He pointed out that new buildings and roads prevented rainwater absorption and increased the frequency and severity of floods. After the 100-year flood in 2011, a new city land use regulation was finally negotiated, as an official from PDPT explained. The new plan has been in an approval process since 
2015 and is expected to be enforced by $2019 / 20$. This strategy will turn KKC into a compact city center of major economic growth. Western PUKKC will be designated as rural residential and agricultural, while Eastern PUKCC, including Pra Lab, will become a rural and agricultural conservation area. He noted that this would prevent further infrastructure development and maintain the area as wetland and farmlands.

Impervious areas in KKC: A KKCM official explained that KKC has an impervious area of 80 percent in 2017. An official from PDPT observed that the increasing loss of pervious surfaces in KKC contributes to the rainwater runoff from the city to Pra Lab. The major road drainage piping system in KKC, as the KKCM official also stated, was designed for impervious areas below 10 percent and followed criteria from 1997. During heavy rainfall, the carrying capacity of the pipes had been insufficient and caused more flash floods in the city. However, he stressed that new drainage pipes in KKC would only mitigate flash floods in the city and not reduce the magnitude of flooding in Pra Lab.

Land and house elevation: Officials from both KKCM and PLM stressed that the water runoff regulations for land and house elevation, as defined in the Building Control Act 8, have and are not properly implemented in PUKKC. The enforcement of the regulations, as reported by a PLM official, is poorly monitored because of the local government's financial and human resources constraints.

Flood protection infrastructure: The RID stated PUKKC has three major kinds of flood protection infrastructure: a floodwall along the rivers, water pumps along Chi River and a recently established watergate with pumps downstream of Pra Keu stream. According to the RID, the capacity of the infrastructure may not be sufficient to address severe floods but building a watergate upstream of Pra Keu stream, for example, as PLM and other municipalities have demanded, would be too expensive and merely move the flooding to another area during heavy rainfall. An official from CRBO also highlighted that efficient water governance is problematic in PUKKC due to its limited decision-making power and conflicting interests of responsible governmental agencies.

Wastewater treatment: A KKCM official explained that there is one wastewater treatment plant in KKC, which only services 80 percent of the municipality. Most untreated wastewater from PUKKC, as an official from the REO10 stressed, is directly discharged into Pra Keu stream causing high levels of pollution. The official further stated that according to water quality standards of the National Pollution Control Department, the stream's water quality is not suitable for consumption or agriculture; Pra Lab community, however, indicate using the stream water for major farming activities.

\section{Discussion and Conclusions}

We provide an assessment of the livelihood vulnerability of Pra Lab communities to flood presented through a LVI and LVI-IPCC, as well as a list of key infrastructure problems of unplanned urbanization in PUKKC. The approach of constructing vulnerability indices may not be applicable for other areas and households because we used indicators that were developed and based on data for the specific local context of the study. We believe that this approach is an attempt to illustrate the reality of Pra Lab as livelihood vulnerability is dynamic and difficult to represent in one index. Despite that, we chose this analysis because we can focus on various dimensions of livelihood. Household vulnerabilities to flood are not included in public flood statistics, which usually only record losses at the macroeconomic level [49]. Thus, our indices can be used as assessment tools for policy formulation and public communication.

Our LVI indicates that Pra Lab communities are only moderately vulnerable to flood while their physical and financial vulnerability are highest. These weaknesses are illustrated by long floodwater retention in houses and on farmland, inaccessibility of streets during flood, lack of wastewater treatment system, high debts, low or no income and insufficient government compensation. We believe that if livelihood vulnerabilities in Pra Lab continue to increase, new urban poverty may emerge. Our results confirm a link between Pra Lab's reliance on an agricultural livelihood and their high financial instability. Hence, we claim that more alternative income generation through nonfarm jobs will be decisive in reducing their livelihood vulnerability to flood. Even though most household head's 
in Pra Lab may be not skilled for nonfarm work, the global trend of younger generations exiting agriculture could be supportive for a shift from rural to urban livelihood in Pra Lab. We suggest that urbanization can increase Pra Lab's adaptive capacity by providing more secure employment opportunities in the urban center, which outweighs the vulnerabilities unique to urbanization.

Our analysis shows that Pra Lab's livelihoods are closely intertwined with urbanization patterns and climate variation. We found that key infrastructure problems of urbanization in PUKKC contribute to flood risks in Pra Lab and, hence, impact multiple dimensions of livelihood vulnerability in Pra Lab. We assert that mainstreaming urban planning measures such as a climate-sensitive land use plan into flood management policies could mitigate flood risks and livelihood vulnerability in Pra Lab. However, our findings also stress that the development and implementation of these measures have shortcomings. For example, the new land use plan constrains certain infrastructure development in floodplain areas like Pra Lab but still favors further reduction of pervious area in KKC. This means that despite a new plan, the rainwater runoff from the city, in combination with anticipated stronger rainfall, is more likely to increase than decrease. Thailand's highly centralized administrative system [50,51], with its slow and redundant bureaucracy or overlapping responsibilities, further hampers policy-makers in adopting relevant flood reducing urban planning measures. In conclusion, we suggest that governmental flood management agencies reconsider building more conventional flood protection measures, such as watergates and floodwalls. Instead, we recommend increasing pervious surfaces that would slow down rainwater runoff through mainstreaming non-structural measures such as a risk-sensitive land use plan into flood management.

Author Contributions: Astrud Lea Beringer and Jutamas Kaewsuk conceived and designed the assessment approach; Astrud Lea Beringer and Jutamas Kaewsuk performed the assessment; Astrud Lea Beringer analyzed the data; Astrud Lea Beringer wrote the paper.

Acknowledgments: This research was conducted through the Urban Climate Resilience in Southeast Asia (UCRSEA) Partnership, supported by a five-year International Partnerships for Sustainable Societies (IpaSS) grant and funded by both the International Development Research Centre (IDRC) and the Social Sciences and Humanities Research Council of Canada (SSHRC). We thank the Thailand Environment Institute (TEI) in Nonthaburi, Thailand and in particular Dr Pakamas Thinphanga for coordinative assistance. We also thank our mentor Nim Lee for providing substantial revisions of the paper.

Conflicts of Interest: The authors declare no conflict of interest. The founding sponsors had no role in the design of the study; in the collection, analyses, or interpretation of data; in the writing of the manuscript and in the decision to publish the results.

\section{Appendix A}

Table A1. Livelihood Vulnerability Index - Types of Assets, Major- and Sub-Components.

\begin{tabular}{|c|c|c|c|}
\hline Code & Indicator/Sub-Component & Survey-Question/Data Source & Reference \\
\hline \multicolumn{4}{|c|}{ Asset Human (H1) | Major Component Health } \\
\hline H1.1 & $\begin{array}{l}\text { HH with family member with illness } \\
(\%)\end{array}$ & $\begin{array}{l}\text { Is anyone in your family chronically ill or } \\
\text { gets sick very often? }\end{array}$ & Adapted from $[43,52]$. \\
\hline H1.2 & $\begin{array}{l}\text { HH with family member ill due to } \\
\text { floods (\%) }\end{array}$ & $\begin{array}{l}\text { Has anyone in your family gotten } \\
\text { chronically ill or gotten sick very often } \\
\text { due to floods? }\end{array}$ & Adapted from $[53,54]$. \\
\hline H1.3 & $\begin{array}{l}\text { HH with family members with diarrhea, } \\
\text { dengue incident, pneumonia, or skin } \\
\text { infection (during/after flood) (\%) }\end{array}$ & $\begin{array}{l}\text { Has anyone in your family suffered from } \\
\text { diarrhea, dengue, pneumonia, or skin } \\
\text { infection during or after a severe flood? }\end{array}$ & $\begin{array}{l}\text { Developed for the purposes } \\
\text { of this questionnaire. }\end{array}$ \\
\hline H1.4 & $\begin{array}{l}\text { HH with no medical insurance to cover } \\
\text { health services and treatment expenses } \\
\text { (during or after flood) }(\%)\end{array}$ & $\begin{array}{l}\text { Do you have medical insurance to cover } \\
\text { health service and treatment expenses } \\
\text { during and after flood? }\end{array}$ & $\begin{array}{l}\text { Developed for the purposes } \\
\text { of this questionnaire. }\end{array}$ \\
\hline
\end{tabular}


Table A1. Cont.

\begin{tabular}{|c|c|c|c|}
\hline Code & Indicator/Sub-Component & Survey-Question/Data Source & Reference \\
\hline \multicolumn{4}{|c|}{ Asset Human (H2) | Major Component Livelihood Strategy } \\
\hline H2.1 & $\begin{array}{l}\text { Average agricultural livelihood } \\
\text { diversification }[1 / \text { (number of } \\
\text { agricultural livelihood activities }+1)] \\
(1 / \# \text { crops) (range: } 0.20-1)\end{array}$ & $\begin{array}{l}\text { Do you or someone in your household } \\
\text { raise animals? } \\
\text { Do you or someone else in your } \\
\text { household grow crops? } \\
\text { Do you or someone else in your } \\
\text { household farm fish? }\end{array}$ & Adapted from [55]. \\
\hline H2.2 & $\begin{array}{l}\text { HHs dependent on agriculture as major } \\
\text { source of income }(\%)\end{array}$ & $\begin{array}{l}\text { Does your household depend on } \\
\text { agricultural farming as a major source of } \\
\text { income? }\end{array}$ & $\begin{array}{l}\text { Developed for the purposes } \\
\text { of this questionnaire. }\end{array}$ \\
\hline H2.3 & $\begin{array}{l}\text { HHs dependent on fish farming as } \\
\text { major source of income }(\%)\end{array}$ & $\begin{array}{l}\text { Does your household depend on fish } \\
\text { farming as a major source of income? }\end{array}$ & $\begin{array}{l}\text { Developed for the purposes } \\
\text { of this questionnaire. }\end{array}$ \\
\hline $\mathrm{H} 2.4$ & $\begin{array}{l}\text { HHs with agricultural/fish farming } \\
\text { that was affected by flood (\%) }\end{array}$ & $\begin{array}{l}\text { Does your farming (agricultural/fish) get } \\
\text { affected by flood? }\end{array}$ & $\begin{array}{l}\text { Developed for the purposes } \\
\text { of this questionnaire. }\end{array}$ \\
\hline H2.5 & $\begin{array}{l}\text { HHs that use more than } 50 \% \text { of harvest } \\
\text { for own food consumption (\%) }\end{array}$ & $\begin{array}{l}\text { Does your household use more than } 50 \% \\
\text { of your harvest for your own food } \\
\text { consumption? }\end{array}$ & $\begin{array}{l}\text { Developed for the purposes } \\
\text { of this questionnaire. }\end{array}$ \\
\hline H2.6 & $\begin{array}{l}\text { HH with family members employed } \\
\text { outside of Pralab (at least one) (\%) }\end{array}$ & $\begin{array}{l}\text { Do you or someone else in your } \\
\text { household work outside of the } \\
\text { community (at least one; other } \\
\text { municipalities, cities)? }\end{array}$ & Adapted from [55]. \\
\hline H2.7 & $\begin{array}{l}\text { HH with family member unemployed } \\
\text { (during flood season) }(\%)\end{array}$ & $\begin{array}{l}\text { Have you or someone else in your } \\
\text { household become jobless/unemployed } \\
\text { during/after flood? }\end{array}$ & Adapted from [56]. \\
\hline \multicolumn{4}{|c|}{ Asset Human (H3) I Major Component Education } \\
\hline H3.1 & HHs: head illiterate (\%) & $\begin{array}{l}\text { Have you or someone else in your } \\
\text { household not gone to school? }\end{array}$ & Adapted from [52]. \\
\hline H3.2 & $\begin{array}{l}\text { HHs: head with only primary school } \\
\text { education }(\%)\end{array}$ & $\begin{array}{l}\text { Did you or someone else in your } \\
\text { household completed only primary } \\
\text { school or until 6th grade? }\end{array}$ & $\begin{array}{l}\text { Developed for the purposes } \\
\text { of this questionnaire. }\end{array}$ \\
\hline H3.3 & $\begin{array}{l}\text { HHs: head not trained to cope with } \\
\text { flood }(\%)\end{array}$ & $\begin{array}{l}\text { Have you or someone else in your family } \\
\text { not received training on how to cope with } \\
\text { flood? }\end{array}$ & $\begin{array}{l}\text { Developed for the purposes } \\
\text { of this questionnaire. }\end{array}$ \\
\hline \multicolumn{4}{|c|}{ Asset Natural (N1) | Major Component Land } \\
\hline N1.1 & Landless HHs (\%) & Does your household not own land? & Adapted from [56]. \\
\hline N1.2 & HHs with land leasing (\%) & Have you owned land before and sold it? & $\begin{array}{l}\text { Developed for the purposes } \\
\text { of this questionnaire. }\end{array}$ \\
\hline N1.3 & HHs with small land (10 rai) (\%) & $\begin{array}{l}\text { Is the land you own/lease/farm smaller } \\
\text { than } 10 \text { rai? }\end{array}$ & $\begin{array}{l}\text { Developed for the purposes } \\
\text { of this questionnaire; } \\
\text { Reference for } 10 \text { rai: [57]. }\end{array}$ \\
\hline \multicolumn{4}{|c|}{ Asset Natural (N2) I Major Component Natural Resources } \\
\hline N2.1 & HHs that did not cultivate 3 rd crop (\%) & $\begin{array}{l}\text { How many crops do you usually cultivate } \\
\text { per year? }\end{array}$ & $\begin{array}{l}\text { Developed for the purposes } \\
\text { of this questionnaire. } \\
\text { Reference for 3rd crop: [58]. }\end{array}$ \\
\hline $\mathrm{N} 2.3$ & $\begin{array}{l}\text { HHs that depend on rainwater for rice } \\
\text { farming }(\%)\end{array}$ & $\begin{array}{l}\text { If your household is doing agricultural } \\
\text { farming, do you depend only on } \\
\text { rainwater for rice farming? }\end{array}$ & $\begin{array}{l}\text { Developed for the purposes } \\
\text { of this questionnaire. }\end{array}$ \\
\hline $\mathrm{N} 2.4$ & $\begin{array}{l}\text { HHs that are affected by wastewater } \\
\text { through stream/rivers for farming (\%) }\end{array}$ & $\begin{array}{l}\text { Do you feel affected by wastewater } \\
\text { contamination of the natural water bodies } \\
\text { (like the Pra Keu stream/Chi river) in } \\
\text { your area? }\end{array}$ & $\begin{array}{l}\text { Developed for the purposes } \\
\text { of this questionnaire. }\end{array}$ \\
\hline \multicolumn{4}{|c|}{ Asset Natural (N3) I Major Component Natural Disasters \& Climate Variability } \\
\hline N3.1 & $\begin{array}{l}\text { Average number of severe floods in the } \\
\text { past } 15 \text { years (No) (range: } 0-6 \text { ) }\end{array}$ & $\begin{array}{l}\text { How many times has this area been } \\
\text { affected by severe floods in the past } 15 \\
\text { years? }\end{array}$ & Adapted from [54]. \\
\hline N3.2 & HHs did not receive flood warning $(\%)$ & $\begin{array}{l}\text { Did your household receive an adequate } \\
\text { flood warning from the government in } \\
\text { the past } 15 \text { years? }\end{array}$ & Adapted from [56]. \\
\hline
\end{tabular}


Table A1. Cont.

\begin{tabular}{|c|c|c|c|}
\hline Code & Indicator/Sub-Component & Survey-Question/Data Source & Reference \\
\hline N3.3 & $\begin{array}{l}\text { Mean standard deviation of average } \\
\text { precipitation by month (average } \\
10-15 \text { years) }\end{array}$ & 2002-2017: provincial data & [16] \\
\hline \multicolumn{4}{|c|}{ Asset Social (S1) I Major Component Socio-Demography } \\
\hline S1.1 & $\begin{array}{l}\text { Dependency ratio }(<15 \text { and }>65 \text { years }) \\
-(((\text { number of people aged }<15)+ \\
(\text { number of people aged }>65)) /(\text { number } \\
\text { of people aged } 15-64)) \times 100(\%)\end{array}$ & $\begin{array}{l}\text { Could you please list the ages and sexes } \\
\text { of every person who eats and sleeps in } \\
\text { this house on a regular basis? }\end{array}$ & Adapted from [52]. \\
\hline S1.2 & $\begin{array}{l}\text { Female HHs head (male away from } \\
\text { home }>6 \text { months per year) }(\%)\end{array}$ & $\begin{array}{l}\text { Are you the head of the family? } \\
\text { Does he/she live in your household? }\end{array}$ & Adapted from [52]. \\
\hline S1.3 & Average family members in $\mathrm{HHs}(\%)$ & $\begin{array}{l}\text { How many family members do you have } \\
\text { in your households? }\end{array}$ & Adapted from [52]. \\
\hline S1.4 & $\begin{array}{l}\text { HHs moved into area despite knowing } \\
\text { that it is a flood prone area }(\%)\end{array}$ & $\begin{array}{l}\text { Did you move to Pralab area from } \\
\text { another area? } \\
\text { If yes, when did you move to Pralab? } \\
\text { Did you know that Pralab is a } \\
\text { flood-prone area when you moved here? }\end{array}$ & $\begin{array}{l}\text { Developed for the purposes } \\
\text { of this questionnaire. }\end{array}$ \\
\hline \multicolumn{4}{|c|}{ Asset Social (S2) I Major Component Social Networks } \\
\hline S2.1 & HHs received help because of flood (\%) & $\begin{array}{l}\text { Have relatives or friends helped you } \\
\text { because of floods? } \\
\text { Did you receive support from the } \\
\text { government during or after heavy flood? }\end{array}$ & Adapted from [52]. \\
\hline S2.2 & $\begin{array}{l}\text { HHs not engaged in neighborhood } \\
\text { helping network during flood (\%) }\end{array}$ & $\begin{array}{l}\text { Has your community a collaborative } \\
\text { neighborhood network for flood relief } \\
\text { (during and after flood)? If yes, do you } \\
\text { participate in this network? }\end{array}$ & $\begin{array}{l}\text { Developed for the purposes } \\
\text { of this questionnaire. }\end{array}$ \\
\hline S2.3 & $\begin{array}{l}\text { HHs experience no solidarity in } \\
\text { area }(\%)\end{array}$ & $\begin{array}{l}\text { Do you experience strong collaboration or } \\
\text { solidarity in your neighborhood during } \\
\text { and after flood? }\end{array}$ & $\begin{array}{l}\text { Developed for the purposes } \\
\text { of this questionnaire. }\end{array}$ \\
\hline \multicolumn{4}{|c|}{ Asset Physical (P1) I Major Component Housing and Means of Production } \\
\hline P1.1 & $\begin{array}{l}\text { HHs with poor quality housing } \\
\text { (semi-constructed house/thatched } \\
\text { roof) }(\%)\end{array}$ & $\begin{array}{l}\text { Is your house semi-constructed or } \\
\text { thatched roofed? }\end{array}$ & $\begin{array}{l}\text { Developed for the purposes } \\
\text { of this questionnaire. }\end{array}$ \\
\hline P1.2 & $\begin{array}{l}\text { HHs with housing affected by flood } \\
\text { (partially to totally submerged) (\%) }\end{array}$ & $\begin{array}{l}\text { Is your house usually affected by the } \\
\text { flood (partially to totally submerged)? }\end{array}$ & $\begin{array}{l}\text { Developed for the purposes } \\
\text { of this questionnaire. }\end{array}$ \\
\hline P1.3 & $\begin{array}{l}\text { HHs experience floodwater in area for } \\
\text { more than } 7 \text { days }(\%)\end{array}$ & $\begin{array}{l}\text { What was the longest duration } \\
\text { floodwater has lasted in your area? }\end{array}$ & $\begin{array}{l}\text { Developed for the purposes } \\
\text { of this questionnaire. }\end{array}$ \\
\hline P1.4 & $\begin{array}{l}\text { HHs experience floodwater in house for } \\
\text { more than } 7 \text { days }(\%)\end{array}$ & $\begin{array}{l}\text { What was the longest duration } \\
\text { floodwater has lasted in your house? }\end{array}$ & $\begin{array}{l}\text { Developed for the purposes } \\
\text { of this questionnaire. }\end{array}$ \\
\hline P1.5 & $\begin{array}{l}\text { HHs that report no access to means of } \\
\text { production }(\%)\end{array}$ & $\begin{array}{l}\text { Does your household have access to } \\
\text { means of production like raw materials to } \\
\text { improve housing? }\end{array}$ & Adapted from [53]. \\
\hline P1.6 & $\begin{array}{l}\text { HHs that have no or only motorbike as } \\
\text { private means of transportation (\%) }\end{array}$ & $\begin{array}{l}\text { Do you have any private means of } \\
\text { transportation? }\end{array}$ & Adapted from [56]. \\
\hline \multicolumn{4}{|c|}{ Asset Physical (P2) | Major Component Urban Systems } \\
\hline P2.1 & $\begin{array}{l}\text { HHs that report no access to } \\
\text { wastewater treatment plant (\%) }\end{array}$ & $\begin{array}{l}\text { Is your household connected to the } \\
\text { wastewater treatment plant? }\end{array}$ & $\begin{array}{l}\text { Developed for the purposes } \\
\text { of this questionnaire. }\end{array}$ \\
\hline P2.2 & $\begin{array}{l}\text { HHs that report no consistent water } \\
\text { supply and/or electricity during } \\
\text { flood }(\%)\end{array}$ & $\begin{array}{l}\text { Does your household have no consistent } \\
\text { water supply and/or electricity during } \\
\text { flood? }\end{array}$ & $\begin{array}{l}\text { Developed for the purposes } \\
\text { of this questionnaire. }\end{array}$ \\
\hline $\mathbf{P} 2.3$ & $\begin{array}{l}\text { HHs that report no adequate access to } \\
\text { roads and streets during flood (\%) }\end{array}$ & $\begin{array}{l}\text { Do you have no adequate access to roads } \\
\text { and streets during flood? }\end{array}$ & Adapted from [56]. \\
\hline \multicolumn{4}{|c|}{ Asset Financial (F1) I Major Component Finance and Income } \\
\hline F1.1 & $\begin{array}{l}\text { HHs borrowed money (more frequently } \\
\text { after severe flooding) (\%) }\end{array}$ & $\begin{array}{l}\text { Have you borrowed money frequently } \\
\text { after a severe flood? }\end{array}$ & Adapted from [55]. \\
\hline F1.2 & $\begin{array}{l}\text { HHs that report to obtain not enough } \\
\text { savings to recover from flood } \\
\text { damages (\%) }\end{array}$ & $\begin{array}{l}\text { Were your savings enough to recover } \\
\text { from the damages you incurred from the } \\
\text { flood? }\end{array}$ & $\begin{array}{l}\text { Developed for the purposes } \\
\text { of this questionnaire. }\end{array}$ \\
\hline
\end{tabular}


Table A1. Cont.

\begin{tabular}{llll}
\hline Code & \multicolumn{1}{c}{ Indicator/Sub-Component } & \multicolumn{1}{c}{ Survey-Question/Data Source } & Reference \\
\hline F1.3 & $\begin{array}{l}\text { HHs that report large financial } \\
\text { debts (\%) }\end{array}$ & $\begin{array}{l}\text { Do you or anyone in your household } \\
\text { have any large financial debts? }\end{array}$ & $\begin{array}{l}\text { Developed for the purposes } \\
\text { of this questionnaire. }\end{array}$ \\
\hline F1.4 & $\begin{array}{l}\text { HHs that report significant income } \\
\text { reduction or no income due to flood } \\
\text { damage in agricultural/fish } \\
\text { farming (\%) }\end{array}$ & $\begin{array}{l}\text { Have you experienced significant income } \\
\text { reduction or no income due to flood and } \\
\text { harvest loss in agricultural/fish farming? }\end{array}$ & Adapted from [56]. \\
F1.5 & $\begin{array}{l}\text { HHs that did not have insurance or } \\
\text { received compensation to recover from } \\
\text { losses (\%) }\end{array}$ & $\begin{array}{l}\text { Have you had any insurance or received } \\
\text { compensation that helped you recover } \\
\text { your losses? }\end{array}$ & Adapted from [56]. \\
\hline F1.6 & $\begin{array}{l}\text { HHs with net HHs income lower than } \\
\text { 100,000 THB/year }(\%)\end{array}$ & What is your average household income? & $\begin{array}{l}\text { Def this questionnaire. } \\
\text { Reference for 100,000 THB } \\
\text { benchmark: [57]. }\end{array}$ \\
\hline
\end{tabular}

Note: Some indicators such as the Livelihood Diversity Index were created because an increase in the crude indicator, in this case, the number of livelihood activities undertaken by a household, decreases vulnerability (e.g., a household who farms fish and rice and raises animals is less vulnerable than a household who only farms fish and rice). Thus, we developed a number that reflects this calculation and gives higher values to households with a lower number of livelihood activities by using the inverse of the crude indicator.

Table A2. Summary of the Livelihood Vulnerability Index results for all assets and components.

\begin{tabular}{|c|c|c|c|c|c|}
\hline Asset & Major Component & Indicator Code & Unit & Observed Value & Index \\
\hline \multirow[t]{5}{*}{ Human (H2) } & Health Vulnerability & & & & 0.223 \\
\hline & & H1.1 & $\%$ & 46.8 & 0.468 \\
\hline & & H1.2 & $\%$ & 20.3 & 0.203 \\
\hline & & H1.3 & $\%$ & 17.7 & 0.177 \\
\hline & & H1.4 & $\%$ & 4.2 & 0.042 \\
\hline \multirow[t]{8}{*}{ Human (H2) } & Livelihood Strategy V & lnerability & & & 0.407 \\
\hline & & H2.1 & $\begin{array}{c}1 / \# \\
\text { crops }\end{array}$ & 0.5 & 0.342 \\
\hline & & H2.2 & $\%$ & 50.6 & 0.506 \\
\hline & & H2.3 & $\%$ & 7.2 & 0.072 \\
\hline & & H2.4 & $\%$ & 70.4 & 0.704 \\
\hline & & H2.5 & $\%$ & 64.0 & 0.640 \\
\hline & & H2.6 & $\%$ & 45.8 & 0.458 \\
\hline & & H2.7 & $\%$ & 12.7 & 0.127 \\
\hline \multirow[t]{4}{*}{ Human (H3) } & Education Vulnerabili & & & & 0.442 \\
\hline & & H3.1 & $\%$ & 8.4 & 0.084 \\
\hline & & Н3.2 & $\%$ & 87.3 & 0.873 \\
\hline & & H3.3 & $\%$ & 37.0 & 0.370 \\
\hline \multirow[t]{4}{*}{ Natural (N1) } & Land Vulnerability & & & & 0.357 \\
\hline & & N1.1 & $\%$ & 13.1 & 0.131 \\
\hline & & $\mathrm{N} 1.2$ & $\%$ & 24.1 & 0.241 \\
\hline & & N1.3 & $\%$ & 70.0 & 0.700 \\
\hline \multirow[t]{4}{*}{ Natural (N2) } & Natural Resources $\mathrm{Vu}$ & erability & & & 0.501 \\
\hline & & N2.1 & $\%$ & 95.8 & 0.958 \\
\hline & & $\mathrm{N} 2.2$ & $\%$ & 7.9 & 0.079 \\
\hline & & $\mathrm{N} 2.3$ & $\%$ & 46.6 & 0.466 \\
\hline \multirow[t]{4}{*}{ Natural (N3) } & Natural disasters \& cl & nate variability & & & 0.217 \\
\hline & & N3.1 & No & 2.3 & 0.152 \\
\hline & & N3.2 & $\%$ & 26.0 & 0.260 \\
\hline & & N3.3 & $\mathrm{mm}$ & 98.6 & 0.241 \\
\hline
\end{tabular}


Table A2. Cont.

\begin{tabular}{|c|c|c|c|c|c|}
\hline Asset & Major Component & Indicator Code & Unit & Observed Value & Index \\
\hline \multirow[t]{5}{*}{ Social (S1) } & \multicolumn{4}{|c|}{ Socio-Demography Vulnerability } & 0.193 \\
\hline & & S1.1 & Ratio & 32.9 & 0.329 \\
\hline & & S1.2 & $\%$ & 26.7 & 0.267 \\
\hline & & S1.3 & Persons & 4.4 & 0.044 \\
\hline & & S1.4 & $\%$ & 13.1 & 0.131 \\
\hline \multirow[t]{4}{*}{ Social (S2) } & \multicolumn{4}{|c|}{ Social Networks Vulnerability } & 0.322 \\
\hline & & S2.1 & $\%$ & 51.5 & 0.515 \\
\hline & & S2.2 & $\%$ & 33.8 & 0.338 \\
\hline & & S2.3 & $\%$ & 11.4 & 0.114 \\
\hline \multirow[t]{7}{*}{ Physical (P1) } & \multicolumn{4}{|c|}{ Housing and Means of Production Vulnerability } & 0.398 \\
\hline & & P1.1 & $\%$ & 1.3 & 0.013 \\
\hline & & P1.2 & $\%$ & 18.6 & 0.186 \\
\hline & & P1.3 & $\%$ & 76.8 & 0.768 \\
\hline & & P1.4 & $\%$ & 81.4 & 0.814 \\
\hline & & P1.5 & $\%$ & 25.0 & 0.250 \\
\hline & & P1.6 & $\%$ & 35.9 & 0.359 \\
\hline \multirow[t]{4}{*}{ Physical (P2) } & \multicolumn{4}{|c|}{ Urban Systems Vulnerability } & 0.607 \\
\hline & & P2.1 & $\%$ & 92.0 & 0.920 \\
\hline & & $\mathbf{P} 2.2$ & $\%$ & 30.4 & 0.304 \\
\hline & & $\mathbf{P} 2.3$ & $\%$ & 59.8 & 0.598 \\
\hline \multirow[t]{7}{*}{ Financial (F1) } & \multicolumn{4}{|c|}{ Finance and Income Vulnerability } & 0.485 \\
\hline & & F1.1 & $\%$ & 16.9 & 0.169 \\
\hline & & F1.2 & $\%$ & 32.1 & 0.321 \\
\hline & & F1.3 & $\%$ & 52.3 & 0.523 \\
\hline & & F1.4 & $\%$ & 77.3 & 0.773 \\
\hline & & F1.5 & $\%$ & 53.2 & 0.532 \\
\hline & & F1.6 & $\%$ & 59.1 & 0.591 \\
\hline \multicolumn{5}{|c|}{ Livelihood Vulnerability Index (Weighted average of H, N, S, P, F) } & 0.385 \\
\hline
\end{tabular}

\section{Appendix B. In-Depth Interview Questionnaires}

\section{Household Questionnaire}

1. Name:

2. Age:

3. Present Address:

4. Gender:

5. Number of household members:

6. Sources of income/employment:

7. Land/house ownership

8. Land/house rent:

\section{Before Flood}

9. What is your understanding or definition of floods?

10. How do you distinguish regular floods and severe floods such as in 2008 and 2011?

11. Have you experienced any severe floods before in Pra Lab? If so, how many times and what did you learn about floods through your past experience?

12. When did you feel the impact of flooding becoming more precarious or severe? Why?

13. Were you worried about floods before the severe floods in 2008 and 2011? Did you think about moving away due to flooding?

14. How would you describe Pra Lab community? 
15. Is your community cooperative or do you have many conflicts?

16. Have you observed or experienced any significant changes in Pra Lab community throughout the past regarding income level, land prices, solidarity, infrastructure or migration?

17. Do you or any household members have any pre-existing health problems or disabilities?

18. Do you have a good network of friends/family/neighbors who would help during flooding?

19. Do you and/or any household member have health insurance? If yes, which one?

During Flood

20. What did and do you usually prepare for the floods before they came/come?

21. During which floods did the floodwater come to your house?

22. How long did flooding last? How high did the water get?

23. Where does floodwater usually come from in your village?

24. How quickly does the water come in? Is the water quality good or bad?

25. If you farm, how long does floodwater stay in the fields? When did/does flood water start affecting your crop/harvest?

26. Were you and other household members affected by floods? How?

27. Have you or your household evacuated because of a flood? If so, for how long and why? If not, why not?

28. Do you think there is wastewater contamination in the flood water? If yes, why?

29. Did you know that the wastewater treatment plant is affecting natural water bodies?

30. Have you ever received adequate warning from the government about the floods before?

31. In your opinion, what causes floods in Pra Lab?

32. Is there someone to blame for the floods? If so, who? Do you think the cause of floods is heavy rain or the low land elevation? Why?

33. Do you know other people in the village/Pra Lab who were badly affected by floods before (such as death, illness, etc.)? Why do you think these people were affected more than others?

34. Do you think it's fair or just that Pra Lab was or is more affected by flood than other municipalities in Peri-Urban Khon Kaen City? Why or why not?

35. Do you think your village gets flooded more than other villages in Pra Lab? If so, why or why not?

36. Is the water level equal throughout your village or Pra Lab during flood? If not, why?

37. Were you surprised by how much water there was and for how long it stayed?

Flood Loss and Response

38. What kind of direct losses have you incurred from floods? How different are losses due to severe foods?

39. How was your house affected? How was your agricultural land/business affected?

40. What kind of indirect losses from floods have you experience before (such as absence at work place, school, difficult reach work place, health problems, loss of convenience as shops and convenience stores, closed pharmacy)?

41. Have floods caused stress for you and your family?

42. What did you do to address flood damages for land, housing and health? How did you provide food for your household? What did you do to get rid of water in your house and on your land?

43. What did you do to respond to the floods in terms of protecting your agricultural production?

44. If you do fish farming, did the flood affect your farming? If yes, how? If no, why not?

45. How did you learn to cope with floods? How did you receive knowledge (from the community, neighborhood, TV or government?

46. How did the government help you to respond to floods in Pra Lab?

47. Do you think the government's help was adequate?

48. Do you think the government does enough to improve the flood situation in Pra Lab?

49. Do you know about any current approaches of the government to tackle flooding in Pra Lab?

50. Have any other groups helped you, such as non-governmental organizations or private firms during flood?

51. Do you think your community can cope well with floods compared to other municipalities/ communities in Peri-Urban Khon Kaen City?

52. What is your assessment of Pra Lab municipality's role in flooding in Pra Lab? 
53. What is your assessment of the role of the Provincial Public Work's and Town and Country Planning Authority in flooding in Pra Lab?

54. What is your assessment of the role of Khon Kaen City Municipality in flooding in Pra Lab?

\section{Recovery}

55. After floodwater is gone, what do you usually do?

56. Have you received any flood compensation from the government before? Was it sufficient to cover flood losses?

57. Did you have any insurance which helped you to recover from pervious flood losses? If so, what kind of insurance was and how much did you receive? If not, why did you not have any insurance?

58. Have you received support from any other groups such as NGOs and private firms after flooding before?

59. Were your savings sufficient to recover from flood damages?

60. What impacts have floods had on your life?

Aftermath

61. What has Pra Lab municipality done since floods became worse?

62. Are the municipality's actions/activities adequate? If so, why/why not?

63. Did your trust in authority change at all after experiencing more severe floods?

64. Did your view of the government change?

65. Does Pra Lab community have any actions in mind to prepare for future severe floods?

66. Do you personally have any actions in mind to prepare for future floods?

67. What do you recommend should be done to mitigate flooding in Pra Lab?

68. Do you think Pra Lab will be flooded badly again soon? If so, do you feel prepared?

\section{Policy-Maker Questionnaire}

1. Did flooding in your municipality become increasingly worse in the past 15 years? How?

2. Do you have any documents on flood damage and flood compensations that you could share with us?

3. How do you think does poor land use contribute to flooding in Peri-Urban Khon Kaen City?

4. How did land speculation and real estate market contribute to flooding?

5. How did water management policy create exposure to flood and in particular in Pra Lab? What are examples, such as in terms of dams and flood protection infrastructure?

6. Do you think wastewater overflow has a severe impact on the environment and livelihood of people in Pra Lab, in particular in the event of flood in Pra Lab?

7. Have people received flood warnings in time?

8. What did you do or are doing to help people to cope with floods?

9. What are other approaches that could help to mitigate flood in Peri-Urban Khon Kaen City, in particular in Khon Kaen City and Pra Lab?

10. Do you think that the residents in Pra Lab are more vulnerable to floods than residents in Khon Kaen City who are exposed to flash floods in certain areas? Why do you think so?

11. How relevant do you think is stronger cooperation among other municipalities for tackling the flooding in Peri-Urban Khon Kaen City?

12. Do you have policies that deal directly with flooding? Do you have a disaster preparedness and prevention plan?

13. What are the aims of such policies? What are the main problems that these policies aim to solve? Are those policies sufficient to tackle flooding in Pra Lab?

14. How do you think does land use planning contribute to flooding in Peri-Urban Khon Kaen City? How important do you consider land use planning as a flood mitigation tool for Pra Lab?

15. Why are drainage systems in certain areas not efficient enough in the event of heavy rainfall?

16. Will efforts such as the newly established pump in Pralab be a long-term solution to improve flood protection and to mitigate flood? What are the problems?

17. Do you think improved land use planning and water management in Khon Kaen City could mitigate the flood risk in Peri-Urban Khon Kaen City and particularly in Pra Lab? 


\section{References}

1. Promphakping, B.; Inmuong, Y.; Photaworn, W.; Phongsiri, M.; Phatchanay, K. Climate Change and Urban Health Vulnerability. Asian Cities Climate Resilience Working Paper Series 31.2016. Available online: http:/ / pubs.iied.org/pdfs/10774IIED.pdf (accessed on 20 March 2017).

2. Yongvanit, S.; Thungsakul, N. The National Economic and Social Development Plan as an Urban Driver for Khon Kaen City. Reg. Views 2013, 26, 17-26.

3. National Economic and Social Development Board. The Twelfth National Economic and Social Development Plan (2017-2021). Available online: http:/ / www.nesdb.go.th/nesdb_en/ewt_w3c/ewt_dl_link.php?nid= 4345 (accessed on 9 February 2018).

4. Ito, H.; Ko, S.; Watanabe, K.; Fujii, T.; Hayashit, K. Assessment by Land Use Change using SI models in Khon Kaen, Thailand. In Proceedings of the 36th Annual Conference of the International Association for Impact Assessment, IAIA16, Resilience and Sustainability, Aichi-Nagoya, Japan, 11-14 May 2016.

5. Northeastern Meteorological Center Khon Kaen. 30-Year Precipitation Statistics for Northeast Thailand; Northeastern Meteorological Center Khon Kaen: Khon Kaen City, Thailand, 2017. (In Thai)

6. Friend, R.; Moench, M. What is the Purpose of Urban Climate Resilience? Implications for Addressing Poverty and Vulnerability. Urban Clim. 2013, 6, 98-113. [CrossRef]

7. Hijioka, Y.; Lin, E.; Pereira, J.J.; Corlett, R.T.; Cui, X.; Insarov, G.E.; Lasco, R.D.; Lindgren, E.; Surjan, A. Asia. In Climate Change 2014: Impacts, Adaptation, and Vulnerability. Part B: Regional Aspects. Contribution of Working Group II to the Fifth Assessment Report of the Intergovernmental Panel on Climate Change; Barros, V.R., Field, C.B., Dokken, D.J., Mastrandrea, M.D., Mach, K.J., Bilir, T.E., Chatterjee, M., Ebi, K.L., Estrada, Y.O., Genova, R.C., et al., Eds.; Cambridge University Press: Cambridge, UK; New York, NY, USA, 2014; pp. 1327-1370.

8. Official Statistics Registration Systems. Available online: http://stat.dopa.go.th/stat/statnew/upstat_age. php (accessed on 8 February 2018). (In Thai)

9. Provincial Department of Public Works and Town \& Country Planning Khon Kaen. Map Showing the Boundary of the Land Use Plan for Khon Kaen City; Provincial Department of Public Works and Town \& Country Planning Khon Kaen: Khon Kaen City, Thailand, 2017. (In Thai)

10. World Bank. Getting Back on Track. Reviving Growth and Securing Prosperity for All; Thailand Systematic Country Diagnosis; World Bank: Washington, DC, USA, 2016.

11. World Bank. The World Bank in Thailand. Overview. Available online: http://www.worldbank.org/en/ country/thailand/overview (accessed on 7 January 2018).

12. National Statistical Office. Summary of Labor Force Survey in Thailand: January 2017. Available online: http:/ / web.nso.go.th/en/survey/data_survey/200260_summary_Jan_2017.pdf (accessed on 7 March 2018).

13. National Statistical Office. Summary of Labor Force Survey in Thailand: December 2012. Available online: http://web.nso.go.th/en/survey/data_survey/560205_LFS+Table_Dec55_Eng.pdf (accessed on 7 March 2018).

14. New York Times. Thai Youth Seeks a Fortune away from the Farm. Available online: http://www.nytimes. com/2012/06/05/world/asia/thai-youth-seek-a-fortune-off-the-farm.html (accessed on 26 February 2018).

15. Tapanapunnitikul, O.; Prasunpangsri, S. Entry of Young Generations into Farming in Thailand. Agricultural Policy Article. Food and Fertilizer Technology Center for the Asian and Pacific Region. 2014. Available online: http:/ / ap.fftc.agnet.org/ap_db.php?id=330 (accessed on 25 January 2018).

16. Thai Meteorological Department. Changes in Temperature and Rainfall over Thailand under Climate Change. 2016. Available online: https://www.tmd.go.th/info/wmo_document_2013.pdf (accessed on 7 March 2018). (In Thai)

17. Voice of America. Thailand Moves to Avoid Repeat of 2011 Flood Catastrophe. Available online: https: / / www.voanews.com/a/thailand-budgets-12-billion-to-avoid-repeat-of-2011-flood-catastrophe147139575/179378.html (accessed on 23 November 2017).

18. Pra Lab Municipality. Urban Development and Growth, and the Impact of Flood; Pra Lab Municipality: Pra Lab, Thailand, 2018. (In Thai)

19. Northeastern Meteorological Center Khon Kaen. Rainfall Index of Khon Kaen Province from 2004 to 2015; Northeastern Meteorological Center Khon Kaen: Khon Kaen City, Thailand, 2017. (In Thai) 
20. Water Resource Management Research Center at the Faculty of Engineering, Rajamangala University of Technology Isan, Khon Kaen University. QGIS Dataset for Khon Kaen Province; Water Resource Management Research Center at the Faculty of Engineering, Rajamangala University of Technology Isan, Khon Kaen University: Khon Kaen City, Thailand, 2014. (In Thai)

21. Pelling, M.; Dill, K. Disaster politics: Tipping points for change in the adaptation of sociopolitical regimes. Prog. Hum. Geogr. 2010, 34, 21-37. [CrossRef]

22. Marks, D. The Urban Political Ecology of the 2011 Floods in Bangkok: The Creation of Uneven Vulnerabilities. Pac. Aff. 2015, 88, 623-651. [CrossRef]

23. Satterthwaite, D.; Huq, S.; Pelling, M.; Reid, H.; Lankao, P.R. Adapting to Climate Change in Urban Areas: The Possibilities and Constraints in Low- and Middle-Income Nations; IIED Human Settlements Discussion Paper Series; Theme: Climate Change and Cities-1; IIED: London, UK, 2007.

24. Friend, R.; Choosuk, C.; Hutanuwatr, K.; Inmuong, Y.; Kittikornkool, J.; Lambregts, B.; Promphakping, B.; Roachanakanan, T.; Thiengburanathum, P.; Thinphanga, P.; et al. Urbanizing Thailand. Implications for Climate Vulnerability Assessments. Asian Cities Climate Resilience Working Paper Series 30.2016. Available online: http:/ / pubs.iied.org/pdfs/10770IIED.pdf (accessed on 11 August 2016).

25. Friend, R.; Thinphanga, P. Chapter 6. Urban Transformations Across Borders: The Interwoven Influence of Regionalisation, Urbanisation and Climate Change in the Mekong Region. In Crossing Borders; Miller, M.A., Douglass, M., Garschagen, M., Eds.; Springer Nature: Singapore, 2018.

26. Roachanakanan, T. Floodways and Flood Prevention in Thailand. Reflections of the great flood in 2011. In Proceedings of the World Flood Protection, Response, Recovery and Drawing up of Flood Risk Management Conference, Bangkok, Thailand, 12-13 September 2012; pp. 85-97.

27. Marshall, F.; Waldman, L.; MacGregor, H.; Mehta, L.; Randhawa, P. On the Edge of Sustainability: Perspectives on Peri-Urban Dynamics; STEPS Working Paper 35; STEPS Centre: Brighton, UK, 2009.

28. Ravetz, J.; Fertner, C.; Nielsen, T.S. The Dynamics of Peri-Urbanization. In Peri-Urban Futures: Scenarios and Models for Land Use Change in Europe; Nilsson, K., Pauleit, S., Bell, S., Aalbers, C., Nielsen, T.S., Eds.; Springer: Berlin/Heidelberg, Germay, 2013; pp. 13-44.

29. Hirsch, P. Revisiting Frontiers as Transitional Spaces in Thailand. Geogr. J. 2009, 175, 124-132. [CrossRef]

30. Huynh, T.; Nguyen, H.; Tran, P.; Tran, D. Vulnerability to Flooding in Peri-Urban Areas in the Context of Urban Development and Climate Change. Lessons from Study on Flooding Assessment in Hoa Tien and Hoa Chau Communes, Hoa Vang District, Da Nang City; Project Article; ISET: Da Nang, Vietnam, 2015.

31. Aparna. Flood Risk Vulnerability of Peri-Urban Communities: The Case of Surat; Knowledge Brief; PARR: Houston, TX, USA, 2017.

32. Mathur, O.P. Urban Poverty in Asia; Asian Development Bank: Mandaluyong City, Philippines, 2014.

33. Ferre, C.; Ferreira, F.H.G.; Lanjouw, P. Is There a Metropolitan Bias? The Inverse Relationship between Poverty and City Size in Selected Developing Countries; Policy Research Working Paper 5508; World Bank: Washington DC, USA, 2010.

34. Ravallion, M.; Chen, S.; Sangraula, P. New Evidence on the Urbanization of Global Poverty; Policy Research Paper Working Paper No. 4199; World Bank: Washington, DC, USA, 2007.

35. World Bank. Global Monitoring Report 2013. Rural-Urban Dynamics and the Millennium Development Goals; World Bank: Washington, DC, USA, 2013.

36. World Bank. Thai Flood 2011. Overview. Rapid Assessment for Resilient Recovery and Reconstruction Planning; World Bank: Washington, DC, USA, 2012.

37. Reed, S.O.; Friend, R.; Toan, V.U.; Thinphanga, P.; Sutarto, R.; Singh, D. "Shared learning” for building urban climate resilience-Experiences from Asian cities. Environ. Urban. 2013, 25, 393-412. [CrossRef]

38. Moench, M.; Tyler, S.; Lage, J. Catalyzing Urban Climate Resilience. Applying Concepts to Planning Practice in the ACCCRN Program (2009-2011); Institute for Social and Environmental Transition-International: Boulder, CO, USA, 2011.

39. Chambers, R.; Conway, G.R. Sustainable Rural Livelihoods: Practical Concepts for the 21st Century; IDS Discussion Paper 296; Institute of Development Studies: Brighton, UK, 1992.

40. DFID. Sustainable Livelihoods Guidance Sheets. London. Available online: http://www.ennonline.net/ dfidsustainableliving (accessed on 27 May 2017). 
41. Moser, C. A Conceptual and Operational Framework for Pro-Poor Asset Adaptation to Urban Climate Change. In Cities and Climate Change: Responding to an Urgent Agenda; Urban Development Series; Hoornweg, D., Freire, M., Lee, M.J., Bhada-Tata, P., Yuen, B., Eds.; World Bank: Washington, DC, USA, 2011.

42. Farrington, J.; Ramasut, T.; Walker, J. Sustainable Livelihoods Approaches in Urban Areas: General Lessons, with Illustrations from Indian Cases; Swedish International Development Cooperation Agency: Stockholm, Sweden, 2002.

43. Hahn, M.B.; Riederer, A.M.; Foster, S.O. The Livelihood Vulnerability Index: A Pragmatic Approach to Assessing Risks from Climate Variability and Change. A Case Study in Mozambique. Glob. Environ. Chang. 2009, 19, 74-88. [CrossRef]

44. Sullivan, C. Calculating the Water Poverty Index. World Dev. 2002, 30, 1195-1210. [CrossRef]

45. UNDP. Training Material for Producing National Human Development Reports. Available online: http:/ /hdr.undp.org/sites/default/files/hdi_training.pdf (accessed on 28 May 2017).

46. Mayring, P. Qualitative Content Analysis. Forum Qualitative Social Research. 2000. Available online: http:/ / www.qualitative-research.net/index.php/fqs/article/view/1089/2385 (accessed on 18 April 2017).

47. XE Currency Converter. Available online: http:/ / xe.com/ (accessed on 6 March 2018).

48. Regional Environmental Office 10 Khon Kaen. Situation of Water Quality in Upper Chi River Basin; Regional Environmental Office 10 Khon Kaen: Khon Kaen City, Thailand, 2013. (In Thai)

49. Noy, I.; Patel, P. Floods and Spillovers: Households after the 2011 Great Flood in Thailand; SEF Working Paper; Victoria University Wellington: Wellington, New Zealand, 2014; Available online: https: / www.victoria.ac. $\mathrm{nz} /$ sef/research/pdf/2014-papers/SEF-Working-Paper-11-2014.pdf (accessed on 4 May 2018).

50. Lebel, L.; Lebel, P. Policy narratives help maintain institutional traps in governance of floods in Thailand. Int. J. Water Resour. Dev. 2017, 1-16. [CrossRef]

51. Lebel, L.; Manuta, J.B.; Garden, P. Institutional Traps and Vulnerability to Changes in Climate and Flood Regimes in Thailand. Reg. Environ. Chang. 2011, 11, 45-58. [CrossRef]

52. DHS. Measure DHS: Model "A" Questionnaire with Commentary for High Contraceptive Prevalence Countries; Basic Documentation; ORC Macro: Calverton, MD, USA, 2001.

53. Can, N.D.; Sophat, S.; Tu, V.H.; Khom, S.; Hoanh, C.T. Vulnerability of Livelihoods in Flood-prone Areas along the Cambodia-Vietnam Border. In Climate Risks, Regional Integration, and Sustainability in the Mekong Region; Lebel, L., Hoanh, C.T., Krittasudthacheewa, C., Daniel, R., Eds.; Strategic Information and Research Development Centre: Petaling Jaya, Malaysia, 2014; pp. 97-122.

54. DRBC. Municipal Questionnaire for the Flood Mitigation Plan. Available online: https://www.nslijhs.com/ Municipal-Questionnaire-For-The-Flood-Mitigation-Plan (accessed on 28 February 2018).

55. World Bank. Survey of Living Conditions: Uttar Pradesh and Bihar. Household Questionnaire; World Bank: Washington, DC, USA, 1997-1998; Available online: http:/ / microdata.worldbank.org/index.php/catalog/ 276 (accessed on 4 May 2018).

56. International Joint Commission Red River Basin Task Force. Assessment of the Social Impact of Flooding for Use in Flood Management in the Red River Basin, 1997. Available online: http:/ /ijc.org/rel/pdf/assess.pdf (accessed on 28 March 2017).

57. Isvilanonda, S.; Bunyasiri, I. Food Security in Thailand: Status, Rural Poor Vulnerability, Some Policy Options; Agricultural and Resource Economics Working Paper No. 2552/1; Food and Fertilizer Technology Center for Asian and the Pacific Region: Taipei, Taiwan, 2009.

58. Ricepedia. Thailand. Available online: http://ricepedia.org/thailand (accessed on 22 May 2017).

(C) 2018 by the authors. Licensee MDPI, Basel, Switzerland. This article is an open access article distributed under the terms and conditions of the Creative Commons Attribution (CC BY) license (http://creativecommons.org/licenses/by/4.0/). 